\title{
NILAI-NILAI YANG TERKANDUNG DALAM TRADISI LISAN BIDUK SAYAK MASYARAKAT DESA JERNIH
}

\section{VALUES CONTAINED IN THE BIDUK SAYAK ORAL TRADITION OF THE SOCIETY OF THE JERNIH VILLAGE}

\author{
Irma Suryani, Dwi Rahariyoso, Rio Yudha Maulana \\ Pendidikan Bahasa Indonesia, Fakultas Keguruan dan IImu Keguruan
}

Naskah diterima: 12 Juni 2018; direvisi: 31 Mei 2019; disetujui: 20 Juni 2019

\begin{abstract}
Abstrak
Tujuan penelitian ini mendeskripsikan nilai-nilai yang terkandung dalam tradisi lisan Biduk Sayak masyarakat desa Jernih. Penelitian ini dilakukan di Desa Jernih Kecamatan Air Hitam Kabupaten Sarolangun Provinsi Jambi.

Unsur-unsur yang terkandung dalam tradisi lisan biduk sayak, terdiri atas seniman tradisi lisan biduk sayak, alat musik, waktu dan tempat pertunjukan, kostum pemain, penonton, dan lagu yang disajikan dalam pementasan tradisi lisan biduk sayak. Keunikan tradisi lisan biduk sayak antara lain, Senimannya terdiri atas: pemain biola dengan senar tiga, pemain kicer/kecir, penggendang ketipung, penggendang celiti, dan vokalis atau penyanyi. Keunikan selanjutnya yaitu, Lirik lagu bentuk seperti pantun dan satu baid dengan baid lainnya saling terkait. Lirik-lirik suatu lagu pada suatu acara misalnya pernikahan, bisa saja digunakan untuk acara turun mandi, yang penting maknanya sampai dan cocok. Nilai-nilai yang terkandung dalam tradisi lisan biduk sayak yaitu nilai budaya, moral, dan religius. Nilai budaya yang ditemukan yaitu ketakwaan, bersyukur, kerukunan, kasih sayang, harapan, pengorbanan, keikhlasan, kesopanan, dan memberi nasihat, Selanjutnya nilai moral yang ditemukan dalam tradisi lisan biduk sayak yaitu tolong menolong dan saling menghargai. Nilai religius yang ditemukan ialah akhlak, keikhlasan, dan kedisiplinan.
\end{abstract}

\section{Abstract}

The purpose of this study is to describe the values contained in the Biduk Sayak oral tradition of Jernih villagers. This research was conducted in the Clear Village of Air Hitam District, Sarolangun Regency, Jambi Province.

The elements contained in the oral biduk tradition consist of artists who say oral biduk, musical instruments, the time and place of the show, the costume of the player, the audience, and the song that is presented in the performance of the oral oral tradition. The uniqueness of my own oral tradition is, among others, the artist consists of: violinist with three strings, kicer / kecir player, ketipung drummer, keen drummer, and vocalist or singer. The next uniqueness is, the lyrics of song forms like pantun and one bait with other bait are interrelated. Lyrics-lyrics of a song at an event such as marriage, can be used for the event to take a bath, the important thing is to arrive and match. The values contained in the oral tradition of the biduk are namely cultural, moral, and religious values. Cultural values found are piety, gratitude, harmony, compassion, hope, sacrifice, sincerity, politeness, and giving advice. Furthermore, the moral value found in the oral tradition is the help and mutual respect. Religious values found are morals, sincerity, and discipline.

\section{Pendahuluan}

Suatu ingatan kolektif dalam masyarakat yang mengandung pesan, nilai dan norma serta kenangan yang menggambarkan kehidupan kelompok masyarakat masih dapat ditemui pada hari ini, seperti yang terkandung dalam tradisi lisan. Tradisi lisan sebagai suatu 
bukti atau kisah tentang masa lalu yang menjelaskan atau mencoba menjelaskan tentang era sebelum orang yang menjelaskan, Miller (dalam Vansina, 2014: 44).

Dalam tradisi lisan, dijumpai berbagai kearifan lokal (local wisdom) yang dapat dilihat melalui kajian-kajian yang mendalam sifatnya. Kearifankearifan lokal ini juga berkaitan erat dengan sejarah peradaban masyarakat yang melahirkan tradisi lisan dan disertai kerifan lokal tersebut. Selain itu, dalam konteks kajian tradisi lisan di seluruh dunia, yang perlu diperhatikan adalah adanya kearifan lokal yang berakar dari berbagai jenis kearifankearifan yang melatarbelakanginya (Takari, 2013:3).

Dalam proses selanjutnya perkembangan tradisi lisan cukup memprihatinkan. Hanya sebagian kecil saja yang dapat didokumentasikan dalam lembaran-lembaran kertas atau bahkan sama sekali belum terdokumentasikan. Perkembangan tradisi lisan hanya menjadi bagian terkecil dari perkembangan budaya pada satu komunitas. Hal itu tentu tidak lepas dari minat para pelaku budaya itu sendiri yang sudah semakin jauh meninggalkan tradisi tersebut. Hal ini diperparah lagi dengan tidak didukungnya tradisi lisan menjadi bagian integral dari proses perkembangan budaya dalam satu komunitas yang cenderung bergerak dinamis saat ini.

Dengan demikian, melakukan pengkajian terhadap nilai-nilai yang terkandung dalam tradisi lisan sangatlah mendesak untuk dilakukan, sebagai bagian dari sadar budaya agar tetap dapat menjaga dan mempertahankan keberadaan tradisi lisan. Nilai-nilai yang terkandung dalam tradisi lisan berupa kearifan-kearifan lokal, maka keberadaannya harus dikelola dengan amat baik.

Menurut Pudentia (2012: 5) dalam pengelolaan tradisi lisan, dapat dilakukan dengan tiga tahapan. Tahapan awal, yaitu Perlindungan yang akan mencakupi kegiatan inventarisasi, klasifikasi, pemetaan, dokumentasi, dan pendaftaran/registrasi secara lokal, regional, nasional dan internasional. Tahap kedua merupakan Pemeliharaaan atau Perawatan yang meliputi kegiatan dokumentasi, pendeskripsian, pementasan, dan pengkajian. Tahap terakhir yaitu, kegiatan revitalisasi hanya akan dapat dilakukan sepanjang masyarakat pemilik masih 
menginginkannya, maka berarti masih berfungsi bagi mereka.

Di Provinsi Jambi, terdapat banyak sekali tradisi lisan, akan tetapi belum terdokumentasikan secara maksimal, bahkan cukup banyak yang belum mengetahui bagaimana tradisi lisan itu pernah hidup dan berkembang di masyarakat Melayu Jambi. Salah satu diantaranya adalah tradisi lisan biduk sayak.

Tradisi lisan biduk sayak merupakan salah satu sastra lisan yang berasal Desa Jernih kecamatan Air Hitam Kabupaten Sarolangun Provinsi Jambi. Dari sisi falsafah, Biduk berarti tempat untuk jalan, perahu, atau diibaratkan dengan bujang dan Sayak berarti tempat, tempurung kelapa, atau diibaratkan dengan gadis. Masyarakat sekitar menyebutnya dengan nama biduk tempurung. Biduk sayak bertujuan memanggil muda-mudi untuk bermain pantun. Selain itu dalam kegiatan menjelang baselang, biduk sayak digunakan untuk mengumpulkan muda-mudi agar membentuk kelompok untuk menugal padi pada esok hari. Tempurung kelapa dengan bentuk bulat melambangkan kesatuan, harmonisasi dan rasa kebersamaan.
Biduk Sayak merupakan tradisi lisan yang diapresiasi oleh masyarakat Desa Jernih sebagai media ekpresi yang lirik-liriknya bermuatan perasaan, nilai persatuan, pesan moral, dan dimensi kemasyarakatan. Selain itu, dalam tradisi lisan biduk sayak mengandung nilai luhur, pesan moral dan pengalaman jiwa yang berharga dan dapat dimanfaatkan sebagai pedoman hidup pada masa sekarang maupun pada masa yang akan datang oleh masyarakat desa Jernih.

Pada mulanya, tradisi lisan biduk sayak ini sangat diminati oleh masyarakat Jernih. Dalam berbagai acara adat seperti pernikahan, beselang, gotong royong dan lain-lain. Meskipun tidak didokumentasikan dalam bentuk tulisan, tradisi lisan ini tetap dilestarikan secara turun-temurun, dari mulut ke mulut. Akan tetapi, seiring berjalannya waktu keberadaan tradisi lisan biduk sayak perlahan mulai jarang dijumpai dalam beberapa kegiatan, kecuali pada acara pernikahan dan itu ketika pihak yang penyelenggara menginginkannya. Dalam perkembangan selanjutnya, keberadaan tradisi lisan berjalan seiring dengan kondisi penuturnya, sehingga jika tidak dilakukan inventarisasi, dokumentasi, pencatatan dan 
pengkajian serta revitalisasi tradisi tersebut akan mengalami kepunahan. Begitu juga dengan tradisi lisan biduk sayak yang dimiliki oleh masyarakat desa Jernih.

Penelitian terhadap tradisi lisan biduk sayak sangat penting dilakukan untuk mengetahui bagaimana keunikan dan nilai-nilai yang terkandung dalam tradisi lisan membentuk dan memberikan pengaruh terhadap kehidupan masyarakat serta memberikan tauladan bagi masyarakat. Melalui pengkajian tradisi lisan biduk sayak, kita akan mengetahui keunikan dan nilai-nilai apa saja yang terkandung di dalamnya.

\section{Tinjauan Pustaka}

\section{Pengertian Tradisi Lisan}

Tol dan Pudentia (dalam Maulid, 2012: 5) mengatakan bahwa tradisi lisan (oral tradition) tidak hanya mencakup cerita rakyat, mite, teka-teki, peribahasa, nyanyian rakyat, dan legenda seperti yang umumnya diduga orang, tetapi juga berkaitan dengan sistem kognitif kebudayaan, seperti sejarah, hukum adat, dan pengobatan tradisional yang disampaikan dari mulut ke mulut.
Lord (dalam Maulid, 2012: 6) juga menjelaskan tentang pewarisan tradisi lisan ke dalam tiga tahap. Tahap yang pertama adalah ketika seorang calon penutur berkeinginan untuk menjadi penutur juga. Tahap kedua dimulai ketika penutur muda tidak saja mendengar, tetapi sudah mulai belajar menuturkan cerita yang sering didengar sebelumnya. Tahap yang ketiga adalah tahap pertumbuhan dan perkembangan kemampuan dalam membuat repertoirnya sendiri. Tukang cerita muda mampu menampilkan cerita secara utuh seperti yang didengar dari penutur senior (gurunya) di hadapan penonton.

Selanjutnya yang paling penting dalam tradisi lisan adalah dijumpai berbagai kearifan lokal yang dapat dilihat melalui kajian-kajian yang mendalam. Kearifan-kearifan lokal ini juga berkait erat dengan sejarah peradaban masyarakat yang melahirkan tradisi lisan dan disertai kearifan lokal tersebut.

\section{Pengertian Nilai}

Nilai dalam bahasa Inggris disebut juga dengan value yang berasal dari bahasa latin yaitu valure yang berarti berguna, mampu, berdaya, berlaku dan kuat. Nilai merupakan 
sesuatu yang dihargai, selalu dijunjung tinggi, serta dikejar oleh manusia untuk memperoleh kebahagiaan hidup (Gusal, 2015: 3).

\section{Nilai Religius}

Religius diambil dari bahasa Latin relego, dimaksudkan dengan menimbang kembali atau prihatin (tentang sesuatu hal). Seseorang yang religius dapat diartikan sebagai manusia yang berarti, yang berhati nurani serius, saleh, teliti, dan penuh dengan pertimbangan spiritual, (Lathief dalam Fatimah, 2015: 120).

Istilah religius sering dipadankan dengan pengertian agama dan kepercayaan. Dengan adanya nilai religius atau nilai keagamaan akan menuntun manusia dalam kehidupan sehari-hari. Dimana agama dapat menjadi petunjuk, pegangan serta pedoman hidup bagi manusia. Hal ini sejalan dengan Saduloh (Marlina dalam Dewi, 2012: 76) yang menyatakan bahwa dengan agama manusia sampai pada suatu pengukuran bahwa semua makhluk yang berada di jagat raya yang mahaluas ini, dimana manusia tidak akan kembali kepadaNya.

\section{Nilai Moral}

Menurut Setyawati (2013: 11) pengertian moral adalah ajaran baik buruk yang diterima umum mengenai perbuatan, sikap, kewajiban, akhlak, dan budi pekerti. Moral dalam karya sastra biasanya mencerminkan pandangan hidup pengarang yang bersangkutan, pandangannya tentang nilai-nilai kebenaran dan hal itulah yang ingin disampaikan kepada pembaca (Nurgiyantoto, 2000: 321).

\section{Nilai Budaya}

Nilai budaya merupakan nilai yang ada dan berkembang di dalam masyarakat. Djamaris (dalam Rohim dan Efendi, tanpa tahun: 206) mengungkapkan bahwa nilai budaya adalah tingkat pertama kebudayaan ideal atau adat, dan merupakan lapisan paling abstrak dengan ruang lingkup dalam kehidupan masyarakat.

Djamaris (dalam Sunarti, 2008: 16) mengungkapkan bahwa nilai budaya dikelompokkan ke dalam lima pola hubungan, yaitu; (1) nilai budaya dalam hubungan manusia dengan Tuhan, (2) nilai budaya dalam hubungan manusia dengan alam, (3) nilai budaya dalam hubungan manusia dengan masyarakat, (4) nilai budaya dalam hubungan manusia dengan orang lain atau sesamanya, (5) nilai budaya dalam hubungan manusia dengan dirinya sendiri. 
Tradisi Lisan Biduk Sayak Masyarakat Desa Jernih

Biduk sayak sendiri mengandung makna filosofis bagi masyarakat desa Jernih. Biduk sendiri berarti perahu, sedangkan Sayak sendiri berarti tempurung, atau tempat. Dalam lirikliriknya menyerupai sebuah pantun. Dalam penyajiannya biduk sayak diiringi oleh alat musik gendang, biola dan rebana.

Biduk sayak dijadikan media hiburan pada saat pelaksanaan acara syukuran naik rumah, baselang, sunatan, dan pesta pernikahan. Biduk sayak menjadi sangat akrab dengan masyarakatnya, hal itu disebabkan karena pertunjukan Biduk sayak memiliki nilai dan pesan yang membawa masyarakat untuk tetap dalam satu kesatuan. Nilai-nilai yang terkandung berupa nilai persatuan, pesan moral dan dimensi kemasyarakatan.

Tradisi lisan Biduk sayak mencakup hasil ekspresi masyarakat desa Jernih yang diwariskan secara turun-temurun dan disebarluaskan secara lisan, yang merupakan produk kreativitas yang mendalam terhadap segala aspirasi, cita-cita, keinginan, dan ide bagi masyarakat lama yang bercorak tradisional.

\section{Masyarakat Desa Jernih Kecamatan Air Hitam}

Adapun masyarakat Desa Jernih yang dimaksud dalam penelitian ini adalah masyarakat yang bermukim di Desa Jernih kecamatan Air Hitam kabupaten Sarolangun. Desa Jernih merupakan nama salah satu desa yang mana desa tersebut menjadi ibukota atau pusat pemerintahan di Kecamatan Air Hitam.

Masyarakat desa Jernih merupakan masyarakat heterogen yang hidup secara rukun dan damai antar suku dengan suku lainnya. Mayoritas Penduduk asli Desa Jernih adalah Suku Bathin, dimana suku ini adalah merupakan suku tertua yang ada di Sarolangun. Beberapa bangunan rumah yang mencirikan tentang arsitektur kehidupan masyarakat Desa Jernih pada masa lampau masih kokoh berdiri. Meski beberapa rumah juga telah beradaptassi dengan arsitektur bangunan masa sekarang. Selain itu, kebiasaan masyarakat yang hidup di tepian sungai sampai saat ini masih tetap bertahan. Dalam pemenuhan kebutuhan sehari-hari, sebagian besar masyarakatnya bergantung kepada hasil kebun dan sawah. 
Metode Penelitian

Pendekatan dan Metode Penelitian

Berdasarkan fokus masalah yang akan diteliti, maka secara metodologis penelitian yang digunakan adalah kualitatif, dan pendekatan deskriptif. Data penelitian berupa kata-kata atau tuturan yang diperoleh dari informan. Metode deskriptif dalam penelitian ini digunakan untuk mengungkapkan keunikan dan nilai-nilai yang terkandung dalam tradisi lisan dengan upaya menelisik tradisi lisan guna melestarikan hubungan sosial masyarakat Desa Jernih.

\section{Tempat dan Waktu Penelitian}

Penelitian ini dilakukan di Desa Jernih Kecamatan Air Hitam Kabupaten Sarolangun Provinsi Jambi. Desa Jernih dijadikan tempat penelitian karena datadata (primer dan sekunder) yang akan dikumpulkan banyak terdapat di Desa Jernih. Penelitian ini berlangsung dari bulan Februari 2018 sampai maret 2018.

\section{Data dan Sumber Data}

Data dalam penelitian ini adalah kalimat, kata maupun ungkapan yang berasal dari tuturan masyarakat desa Jernih. Data tersebut dapat dinyatakan sebagai data primer. Sedangkan data sekunder dalam penelitian ini adalah data yang dapat melengkapi dan membantu memberikan klarifikasi terhadap data primer.

\section{Prosedur Pengumpulan Data}

$\begin{array}{ccc}\text { Dalam } & \text { penelitian ini } \\ \text { menggunakan } & \text { beberapa teknik }\end{array}$
pengumpulan data tertentu yaitu:

a. Observasi/Pengamatan dan Dokumentasi

Teknik pengumpulan data tersebut adalah teknik observasi atau pengamatan Desa Jernih secara langsung. Hal ini bertujuan untuk menggali data primer secara langsung dan mempertajam informasi secara langsung melalui dokumentasi foto.

b. Wawancara

Teknik wawancara dilakukan dengan beberapa pihak pemangku kepentingan (stakeholder) dalam hal ini pemerintah dan masyarakat lokal Desa Jernih baik yang terlibat secara langsung maupun tidak langsung dari segi operasional. Teknik ini bertujuan untuk mendapatkan informasi mengenai kondisi objek penelitian terkini dan peluang ke depan.

\section{Analisis Data}

Secara garis besar tahapan analisis data berupa: (1) Open Coding, artinya membuka diri agar memperoleh variasi data yang lengkap. Dalam kaitan ini, proses memerinci (breaking down), 
memilah (checking) mana data pendukung dan mana yang bukan, memeriksa (examining) satu persatu secara cermat mana data yang akan digunakan, membandingkan (comparing) antara catatan, pengamatan, dan rekaman, mengkonseptualisasikan

(conceptualizing), dan mengkategorikan (categorizing); (2) axial coding, yaitu pengorganisasian kembali data-data yang telah terklarifikasi rapi. Peneliti kemudian melakukan hubungan antar kategori, agar tidak terjadi pengulangan-pengulangan; (3) display coding, artinya peneliti menyajikan beberapa tabel jika ingin menggunakan tabel. Dari tabel akan terbaca bagaimana hubungan antar kategori. Jika tanpa tabel, sajian langsung memaparkan kategori dan analisis mendalam. Gambar-gambar (foto) pendukung, ada baiknya masuk pada bagian ini.

\section{Pemeriksaan Keabsahan Data}

Setelah tahapan analisis dilakukan, maka untuk menguji keabsahan data dilakukan beberapa cara, diantaranya: (1) model triangulasi, artinya mengulang atau klarifikasi aneka sumber. Jika diperlukan triangulasi data, dapat dilakukan dengan cara mencari data-data lain sebagai pembanding. Jika triangulasi pada aspek metode, perlu meninjau ulang metode yang digunakan (dokumentasi, observasi, catatan lapangan dll); (2) pemeriksaan data oleh informan kembali. Hal ini untuk menghindari terjadinya protes oleh informan, yang berakibat pada gugatan; (3) member check dan konsultasi ahli, yakni peneliti dapat menyerahkan data kepada anggota lain dan atau ahli (pembimbing) dari sini akan muncul berbagai saran yang diperlukan guna kesempurnaan; (4) review mitra bestari, artinya menyerahkan data kepada mitra bestari yang dianggap serumpun ilmu. (Endraswara, 2015: 77-78).

\section{Hasil dan Luaran yang Dicari Sejarah Tradisi Lisan Biduk Sayak}

Unsur-Unsur yang Terdapat dalam Tradisi Lisan Biduk Sayak

Unsur-unsur yang terdapat dalam tradisi lisan biduk sayak mengacu kepada bentuk. Pengertian bentuk yang dimaksud dalam tradisi lisan biduk sayak salah satunya adalah seperti yang diungkapkan Djelantik (Apriani, 2012:2) bahwa bentuk merupakan unsur-unsur dasar dari susunan pertunjukan. Unsur-unsur penunjang yang membantu bentuk itu dalam mencapai perwujudannya yang khas 
adalah: seniman, alat musik, kostum dan rias, lagu yang disajikan, tempat pertunjukan, waktu serta penonton.

\section{Waktu dan Tempat Pelaksanaan Biduk Sayak}

Istilah biduk sayak berasal dari dua nama, yaitu biduk yang berarti perahu dan sayak yang berarti tempurung kelapa. Maka dapat diartikan bahwa kita bermain dalam suatu tempat, atau lingkaran. Dalam masa awal pertunjukan biduk sayak tidak jauh dari yang namanya tempat pertunjukan. Dalam prosesi pertunjukan, biasanya muda-mudi dibentuk dua kelompok yang dipisah antara laki-laki dan perempuan yang masing-masing memiliki seorang ketua kelompok. Ketika salah seorang hendak meninggalkan lokasi pertunjukan, maka harus mendapat izin dari ketua kelompoknya. Selama prosesi pertunjukan berlangsung, ada komposisi yang menarik dimana kedua kelompok saling bergantian memainkan pantun (berbalas pantun).

$$
\text { Pertunjukan biduk sayak }
$$
diselenggarakan pada acara pernikahan, hajatan, turun mandi, dan beselang ${ }^{l}$. Acara ini biasanya dipentaskan sekira pukul 20.00 atau selepas sholat isya sampai menjelang pagi hari sekira pukul

\footnotetext{
${ }^{1}$ Menanam/memanen
}

03.00 WIB jika memungkinkan. Dalam pertunjukan biduk sayak kadangkala juga diiringi dengan tarian-tarian, seperti Tari Teluk Kecimbung, Tari Selendang, Tari Piring, Tari Pucuk Pauh, Tari Dana, Tari Jeruk Purut, dan Tari Mainang.

Pertunjukan biduk sayak membutuhkan orang banyak, jadi yang diutamakan dalam pertunjukan ini adalah kekompakan. Selain sebagai hiburan dan juga memori kenangankenangan masa lalu. Sebagaimana pendapat ahli yang mendefinisikan kenangan mungkin adalah hasil yang paling umum dari ingatan manusia. Baik pada saat didorong dengan pertanyaan ataupun tidak, mereka pada umumnya merupakan ingatan dari kejadian-kejadian atau situasi-situasi di masa lampau yang diberikan oleh para pesertanya jauh sesudah kejadian itu berlalu. Kenangan merupakan potongan dari sejarah kehidupan, (Vansina, 2014: 9).

Berdasarkan makna dari sayak yang berarti melingkar, terdapat sebuah nilai komunal yang terbentuk di dalamnya yang secara tidak sadar tradisi itu membentuk masyarakat untuk tetap satu. Selama proses pertunjukan berlangsung, pantun merupakan bagian 
yang tidak terpisahkan. Pasalnya pantun adalah syair lagu dalam biduk sayak itu sendiri.

Sebelum pertunjukan di mulai, para seniman lebih dahulu harus melakukan latihan, hal ini bertujuan untuk menyesuaikan nada dan keramahan dengan penonton. Proses berbalas pantun tidak terpaku pada penyanyi dalam kelompok, namun siapa saja yang berkeinginan melantunkan pantun diperbolehkan untuk bergabung dalam pertunjukan. Menurut tuturan masyarakat, pada masa lalu selepas pertunjukan biduk sayak yang kebanyakan adalah para muda-mudi, selesai pertunjukan ada yang sampai melanjutkan ke jenjang pernikahan. Maka nilai komunal itu sendiri tidak hanya hadir ketika pertunjukan berlangsung, namun di luar itu secara tidak tertulis terbentuk dalam kehidupan masyarakat. Pertunjukan tidak terjadi secara sembarangan. Mereka terjadi pada saat-saat yang tepat selama adanya kegiatan sosial yang dilembagakan dan genre serta isinya terkait dengan kejadian yang dimaksud, (Vansina, 2014: 147).

\section{Lagu yang Disajikan}

Lirik lagu dalam tradisi lisan biduk sayak memiliki bentuk seperti pantun. Adapun lirik lagu yang telah terhimpun dalam penelitian ini adalah sebagai berikut:

1. Lagu Batang Hari

Laki-laki:

Kedang ruso di ujung tanjung

Lagi memakan sianak padi

Kedang duso yang aku tanggung

Aku mengago nantunang kanti

(Besar rusa di ujung tanjung Lagi memakan si anak padi Besar dosa yang aku tanggung Aku mengganggu tunangan kawan)

Perempuan:

Kalau iyo samo nak mandi Samo di rumput padi jarang

Kalau iyo samo nak jadi

Samo diturut untungku malang

(Kalau iya bersama mau mandi Sama di rumput padi jarang Kalau iya sama mau jadi Sama diturut nasibku malang)

Laki-laki:

Tinggi tebing lubuk kepayang Anak nyongikan dalam perahu Ngidak kusedih layodek Nia melayang

Asal lay bakepan layode malaka kau

(Tinggi tebing lubuk kepayang Anak ikan dalam perahu Tidak ku sedih nyawaku melayang

Asal berkafan kain kamu)

Perempuan:

Kalau ado kaco di pintu

Daun dedap paibat nasi

Kalau ado kato maitu

Alang kasedap rayo dihati 
(Kalau ada kaca di pintu Daun dedap pembungkus nasi Kalau ada kata seperti itu Alangkah senang rasa di hati)

Laki-laki:

Kalau ngida mandi ke tanjung Mandi di ulak nan tebat patah Kalau ngida jadi sebandung Abang merajuk dendam dak sudah

(Kalau tidak mandi ke tanjung Mandi di teluk bendungan patah

Kalau tidak jadi bersanding Kami bersedih dendam tidak sudah)

Perempuan:

Kalau iyo samo nak mandi Ayam sereban di bagih duo Kalau iyo samo nak jadi

Kemas beban berangkat kito

(Kalau iya sama mau mandi Ayam sekandang dibagi dua Kalau iya sama mau jadi Kemas barang berangkat kita)

Laki-laki:

Baju apo yang kau pakai

Siang tepasang malam buganti

Ilmu apu yang kau pakai

Siang tabayang malam bamimpi

(Baju apa yang kau pakai

Siang terpasang malam

berganti

Ilmu apa yang kau pakai

Siang terbayang malam termimpi)

Perempuan:

Kutau di padi baru

Rumput manis di tanah tumbuh
Kutau dihati kau

Mulut manih hati dak sungguh

(Aku tau padi baru di tuai

Rumput manis fitnah tumbuh

Aku tau dihati kamu

Mulut manis hati tidak sungguh)

\section{Seniman Tradisi Lisan Biduk Sayak}

Seniman Tradisi lisan biduk sayak yang penulis temui dalam pementasan pada malam itu berjumlah kurang lebih tujuh orang yang memiliki peran masing-masing sesuai bidang keahliannya. Salah satu narasumber menyampaikan bahwa pertunjukan biduk sayak merupakan hobi sekaligus merupakan merupakan upaya dalam menjaga warisan leluhur mereka. Ratarata latar belakang pekerjaan mereka adalah seorang petani dan hanya satu atau dua orang saja yang bekerja di sebuah perusahaan.

Aku, dari aku dikatokan masih bujang-bujang macam ini aku ludah ikut acara ini. Mulai dari SD la mulai nyanyinyanyi kayak ini, kan lagulagu dusun. Jadi biduk sayak ini peninggalan sejarah kami, tradisional. Tapi kalau kami dusun ini, ini kesenian daerah ini hiburan dusun. Kalau dulu acara pengantin atau apu Lay belum adu organ acara ini Lah. Rebana dengan biduk sayak... (wawancara Zaiyin).

Sementara dalam proses belajar dan pewarisan tradisi lisan biduk sayak, 
sebagaimana juga terjadi dalam beberapa tradisi yang berkembang di Indonesia umumnya masih berlaku secara turun-temurun.

Istilahnya, kalau lagulagu ini ado gurunyo. Kalau ini pantun apo kito jawab. Dak ado kita dapat dewek dak. Harus ado melalui apo jugo kan. Ada yang lebih senior. Karno kito nak garang-ngarang dak bisa, walaupun bisa ngarangnyo dak ado tepat dengan jawabannya.

Jadi kalau orang tu bisa melagu, kalau caranyo dak tepat jugo dak biso dak. Jadi istilah tu dido besambut dak tu. Ibarat kita ngomong itu tidak nyambung (wawancara Jamhur).

Berdasarkan penyampaian narasumber di atas, bahwa setiap tradisi melalui proses pewarisan dan proses belajar yang cukup panjang. Ada penyesuaian yang harus dikuasai seniman demi kekhasan sebuah tradisi itu tetap terjaga. Hal ini sejalan pula dengan pandangan Lord (dalam Maulid, 2012: 6) yang menjelaskan tentang pewarisan tradisi lisan ke dalam tiga tahap. Tahap yang pertama adalah ketika seorang calon penutur berkeinginan untuk menjadi penutur juga. Tahap kedua dimulai ketika penutur muda tidak saja mendengar, tetapi sudah mulai belajar menuturkan cerita yang sering didengar sebelumnya. Tahap yang ketiga adalah tahap pertumbuhan dan perkembangan kemampuan dalam membuat repertoirnya sendiri. Tukang cerita muda mampu menampilkan cerita secara utuh seperti yang didengar dari penutur senior (gurunya) di hadapan penonton.

Adapun para seniman dalam tradisi lisan biduk sayak antara lain:

1. Pemain piol (Biola) dengan senar tiga.

2. Pemain Kicer/Kicir.

3. Penggendang Ketipung.

4. Penggendang Celeti/cati.

5. Vokalis/ penyanyi.

\section{Perlengkapan Pementasan}

Musik tampil dalam setiap kegiatan kesenian. Mengingat musik merupakan penopang wajib dari berbagai genre kesenian. Adapun perlengkapan pementasan yang berupa alat musik akan diuraikan dibawah ini.

1. Kicer/Kicir

2. Piol/Biola

3. Gendang Cati

4. Gendang Ketipung

Nilai-Nilai yang Terkandung dalam Tradisi Lisan Biduk Sayak

Nilai Budaya

Djamaris

(1994:

mengungkapkan bahwa nilai budaya 
adalah tingkat pertama kebudayaan ideal atau adat, dan merupakan lapisan paling abstrak dan luas ruang lingkupnya. Tingkat ini adalah ide-ide yang mengkonsepsi hal-hal yang paling bernilai dalam kehidupan masyarakat.

$$
\text { Djamaris (1994: 16-17) }
$$
mengungkapkan bahwa: Nilai budaya dikelompokkan ke dalam lima pola hubungan, yaitu; (1) nilai budaya dalam hubungan manusia dengan Tuhan, (2) nilai budaya dalam hubungan manusia dengan alam, (3) nilai budaya dalam hubungan manusia dengan masyarakat, (4) nilai budaya dalam hubungan manusia dengan orang lain atau sesamanya, (5) nilai budaya dalam hubungan manusia dengan dirinya sendiri.

\section{Nilai Budaya dalam Hubungan Manusia dengan Tuhan}

Nilai Budaya dalam Hubungan Manusia dengan Tuhan Nilai-nilai budaya yang dalam hubungan manusia dengan Tuhan adalah ketakwaan.

\section{Nilai Budaya dalam Hubungan Manusia dengan Alam}

Pemanfaatan alam yang sedemikian banyaknya, bahkan hampir keseluruhan manusia bergantung kepada alam demi kelangsungan hidupnya, sudah sepantasnya kita wajib bersyukur Allah masih berikan kita alam yang masih terjaga.

\section{Nilai Budaya dalam Hubungan Manusia dengan Masyarakat}

Manusia sebagai makhluk sosial sudah semestinya memahami bahwa masyarakat memiliki susunan heterogenitas yang begitu kompleks. Beberapa aspek penting banyak berkembang di sana seperti politik, ekonomi, sosial-kultural dan agama. Nilai budaya dalam hubungan manusia dengan masyarakat yang ada dalam tradisi lisan biduk sayak masyarakat Desa Jernih, yaitu kerukunan.

Kerukunan

Nilai budaya kerukunan yang terdapat dalam tradisi lisan biduk sayak lebih menggambarkan hubungan kolektivitas dalam kehidupan bermasyarakat. Melalui tradisi ini masyarakat penganut tradisi lisan biduk sayak percaya bahwa mereka adalah satu kesatuan yang tidak terpisahkan. Sebuah hubungan integrasi yang disatukan dalam lingkup kebudayaan yang sama.

Hal ini juga didukung oleh narasumber saat kami melakukan wawancara, seperti di bawah ini:

(13) kalau main biasa tidak ada batasan. Umpama kalau kamu berbalas pantun segan kalah, aku juga segan kalah juga. Apalagi 
kalau ada yang janda. Tapi tetap main, tidak ada unsur menyinggung atau menjelek-jelekan. Rayu ada dan bujuk juga ada di situ.

\section{Nilai Budaya dalam Hubungan}

\section{Manusia dengan Manusia Lain}

Nilai budaya dalam hubungan manusia dengan manusia lain yang terdapat dalam tradisi lisan biduk sayak, yaitu kasih sayang, harapan, pengorbanan, ikhlas, kesopanan, dan memberi nasihat.

a) Kasih Sayang

Tradisi lisan biduk sayak yang menggambarkan nilai budaya kasih sayang terjalin di dalam hubungan dalam sesamanya. Kasih sayang yang mendalam ditunjukkan dalam usaha seorang laki-laki untuk merayu kekasihnya. Si laki-laki berusaha sebisa mungkin dalam merayu dengan menggunakan pantun-pantun yang ia kuasai.

Hal ini didukung dengan hasil wawancara yang menjelaskan bagaimana rasa kasih sayang yang terjadi itu begitu tinggi.

(15) iya. Itu lah tadi. Karena sangat menghayati lagu daerah, di Dusun kami pernah terjadi gadis dengan bujang berbalas pantun, selesai pertunjukan biduk sayak langsung ke rumah kepala desa dan menikah. Balas pantunnya itu tadi.

b) Harapan
Nilai budaya harapan ditemukan dalam tradisi lisan biduk sayak berupa harapan kepada seseorang yang dikasihinya, yaitu berupa rayuan agar ia mau menerimanya. Harapan yang mendalam kepada seseorang, terlebih orang tersebut sangat kita sayangi, kehadirannya menjadi sangat penting bagi kita.

c) Rela Berkorban

Dalam tradisi lisan biduk sayak nilai rela berkorban tergambar dalam pantun yang disampaikan selama pertunjukan. Nilai rela berkorban di sini adalah dimana si laki-laki harus merundung kemalangan dan kepahitan dalam hidupnya. Seperti yang terlihat pada kutipan pantun di bawah ini.

Sayang burakit pinang sebatang Tibo di teluk menjadi duo alang busakit dagang menumpang Ayie lah nyo keruh ku laminum jugo

(Sayang berakit sebatang
pinang
Tibo di teluk menjadi dua
Sungguh sakit menumpang
hidup
Air yang keruh kuminum juga)
Tinggi tebing lubuk kepayang
Anak nyongikan dalam perahu
Ngidak kusedih layodek Nia
melayang
Asal Lay bakepan layode malaka
kau


(Tinggi tebing lubuk kepayang Anak ikan dalam perahu Tidak ku sedih nyawaku melayang Asal berkafan kain kamu)

\section{d) Keikhlasan}

Keikhlasan yang dimaksud dalam tradisi lisan biduk sayak adalah sikap rela menanggung segala beban hidup dan kesakitan demi sang kekasih. Selain itu bentuk keikhlasan dalam konteks pertunjukan tradisi lisan tergambar dari sikap suka rela seseorang dalam melantunkan pantun dengan maksud menghibur. Pada kutipan di bawah ini tertuang nilai keikhlasan.

Kalu mangujan ngujan la hari Asal lah jangan sereto guruh bucerai kasih

Kalu nak buang buanglah kami Asal lah nyo jangan seret tuduh

(Kalu mau hujan hujanlah Asal jangan dengan guruh Kalau mau bung buanglah kami Asal jangan beserta tuduhan)

Sayang burakit pinang sebatang Tibo di teluk menjadi duo alang busakit dagang menumpang Ayie lah nyo keruh ku laminum jugo

(Sayang berakit sebatang pinangTibo di teluk menjadi dua Sungguh sakit menumpang hidup Air yang keruh kuminum juga) e) Kesopanan

Dalam konteks tradisi lisan biduk sayak sangat menjunjung nilai kesopanan. Dimana selama proses pertunjukan ada sikap menghormati lawan main dalam berpantun. Sikap tenggang rasa dan tidak menjatuhkan satu sama lain merupakan bentuk penghargan terhadap hak orang lain dan sebagai bentuk nilai kesopanan demi terjaganya persatuan dalam kehidupan bermasyarakat.

(13) kalau main biasa tidak ada batasan. Umpama kalau kamu berbalas pantun segan kalah, aku juga segan kalah juga. Apalagi kalau ada yang janda. Tapi tetap main, tidak ada unsur menyinggung atau menjelek-jelekan. Rayu ada dan bujuk juga ada di situ.

(14) kalau kami dalam berpantun, tidak pernah yang namanya tersinggung. Emosi itu ada, tapi bukan marah. Itu adalah semangat muda. Pokonya seperti itu, kalau menurut yang tua, berjalan masuk rumah itu ada pantun, ada selokonyo.

Setiap masyarakat mempunyai aturan dan tata krama masing-masing. Tetapi, satu hal yang tetap berlaku yaitu adap sopan santun dalam tata pergaulan manusia. Begitu halnya ketika babiduk sayak. Kesopanan yang ditunjukkan yaitu adanya ketaatan terhadap norma, dimana selama pertunjukan muda-mudi dipisah tempat duduknya dan dari setiap 
kelompok muda mudik ditunjuk seorang ketua kelompok. Fungsi dengan adanya ketua kelompok adalah untuk menjaga agar pertunjukan tetap berlangsung tanpa ada suatu hambatan. Namun, sebuah kesepakat bahwa hadirnya ketua kelompok adalah untuk meminta izin. Artinya, setiap anggota yang hendak meninggalkan pertunjukan harus meminta izin terlebih dahulu kepada ketua kelompok. Hal ini dilakukan untuk menghormati keberlangsungan pertunjukan, tuan rumah penyelenggara dan merupakan bagian dari adab.

(26) Itu tergantung dengan orang, ada orang pernikahan, ada hajatan, ada mandi anak kan. Jadi biduk sayak tu maksudnya sayak itu tempurung kelapo, berarti yang main itu dak boleh keluar dari situ. Ini kan, ini tempat, yang pemain dak boleh keluar dari situ dak, harus satu. Kecuali mereka meminta izin, itu maksudnya biduk sayak tu. Di dalam sayak tu istilahnya satu wadah.

f) Memberi Nasihat

Nasihat itu muncul untuk memberi semangat kepada seseorang agar hendaknya tidak berputus asa dalam menjalani kehidupan. Nasihat itu membentuk seseorang untuk tidak berburuk sangka, memandang semuanya secara luas sebelum mengambil sebuah tindakan.
Nilai Budaya dalam Hubungan Manusia dengan Diri Sendiri

Berdasarkan analisis secara teks lagu maupun konteks yang ada selama pertunjukan biduk sayak, maka nilai budaya dalam hubungan manusia dengan diri sendiri yang terdapat dalam tradisi lisan biduk sayak yaitu tanggung jawab, berani, kesabaran, dan menjaga harga diri.

1) Tanggung Jawab

Tanggung jawab timbul karena diterimanya sebuah wewenang, amanah atas dirinya. Rasa tanggung jawab harus melekat pada diri seseorang. Hilang sikap tanggung jawab dari seseorang, maka akan menghilangkan integritas, dan kewibawaan seseorang itu. Dengan demikian, kalau terjadi sesuatu maka seseorang yang dibebani tanggung jawab wajib menanggung segala sesuatunya.

2) Berani

Selain daripada manusia harus memiliki sikap tanggung jawab, dia juga harus memiliki sifat berani. Sifat berani akan menghadirkan sikap rela berkorban, tidak peduli apapun rintangan dan halangannya. Keberanian mampu mengalahkan segala sesuatunya, ketakutan, kelaparan, dan rasa sakit 
bahkan nyawa sekalipun akan ia korbankan.

3) Kesabaran

Nilai kesabaran dalam tradisi lisan biduk sayak menggambarkan sebuah kepasrahan akan nasib yang harus ia hadapi. Pelajaran hidup itu membawanya kepada sebuah kerelaan akan kuasa Tuhan yang menimpa dirinya, dalam satu sisi ia juga harus tetap bangkit dan memperjuangkan hakhaknya.

4) Menjaga Harga Diri

Dalam tradisi lisan biduk sayak nilai yang kemudian muncul adalah sikap malu kepada diri sendiri jika terlihat lemah atau miskin di mata orang lain. Tidak menjadi persoalan jika belum memiliki seorang pendamping, tetapi ketika terlihat lemah, tidak memiliki apa-apa adalah suatu yang sangat memalukan dalam hidupnya. Seolah-olah hidupnya sangat menderita atau akan menggantungkan hidupnya pada orang lain. Nilai inilah yang kemudian menjadi kunci bahwa pantang untuk dirinya bergantung hidup kepada orang lain.

\section{Nilai Moral}

Hartini (dalam Solekah, 2012:12) mengemukakan nilai moral mengandung tiga aspek yaitu: (1) nilai moral yang terkandung dalam hubungan manusia dengan dirinya sendiri; (2) nilai moral yang terkandung dalam hubungan manusia dengan sesama; dan (3) nilai moral yang terkandung dalam hubungan antara manusia dengan alam.

a) Tolong menolong

Dalam tradisi lisan biduk sayak sikap tolong menolong dijumpai selama proses pesiapan hingga terlaksananya pertunjukan biduk sayak. Nilai komunal, persatuan dan kesatuan akan melahirkan nilai bahwa kita harus samasama saling membantu.

b) Saling menghargai dan tidak meremehkan orang lain

Sikap tenggang rasa, tidak saling mengungguli dan menjatuhkan terbentuk dalam tradisi lisan biduk sayak. Rasa persatuan yang tinggi inilah yang melahirkan sifat untuk tidak saling menyakiti dan saling merendahkan.

\section{Nilai Religius}

Dalam menggali nilai religius yang terdapat dalam tradisi lisan biduk sayak, peneliti berpedoman pada pendapat Atmosuwito (dalam Meliani, 2017: 9) yaitu: (1) hubungan manusia dengan Tuhan; (2) hubungan manusia dengan manusia; dan (3) hubungan manusia dengan alam.

a) Akhlak dan Kedisiplinan 
Akhlak dapat berupa akhlak terpuji dan akhlak tercela. Akhlak terpuji adalah perbuatan baik yang dimiliki manusia, seperti: menghormati orang yang lebih tua, menghargai orang yang lebih muda, saling mengasihi antar sesama manusia, dan lain sebagainya. Sebaliknya akhlak tercela adalah perbuatan buruk yang dimiliki manusia, seperti: berbohong, memandang rendah orang lain, durhaka kepada orang tua, dan lain sebagainya. Kedisiplinan merupakan bentuk kepatuhan terhadap aturan yang berlaku. Kedisiplinan dapat pula diartikan sebagai tunduk atau taat terhadap perintah. Sikap disiplin dapat membangun keteraturan dalam hidup. Oleh karena itu, orang yang disiplin biasanya akan mampu memanfaatkan waktunya dengan sebaik mungkin.

b) Ikhlas

Orang yang bersifat ikhlas melakukan sesuatu hanya mengharapkan ridho dari Allah swt. atau tidak didasari oleh rasa pamrih. Keikhlasan yang dimaksud dalam tradisi lisan biduk sayak adalah sikap rela menanggung segala beban hidup dan kesakitan demi sang kekasih. Selain itu bentuk keikhlasan dalam konteks pertunjukan tradisi lisan tergambar dari sikap suka rela seseorang dalam melantunkan pantun dengan maksud menghibur

\section{Kesimpulan}

Unsur-unsur yang terkandung dalam tradisi lisan biduk sayak, terdiri atas seniman tradisi lisan biduk sayak, alat musik, waktu dan tempat pertunjukan, kostum pemain, penonton, dan lagu yang disajikan dalam pementasan tradisi lisan biduk sayak. Keunikan tradisi lisan biduk sayak antara lain, Senimannya terdiri atas: pemain biola dengan senar tiga, pemain kicer/kecir, penggendang ketipung, penggendang celiti, dan vokalis atau penyanyi. Keunikan selanjutnya yaitu, Lirik lagu bentuk seperti pantun dan satu baid dengan baid lainnya saling terkait. Liriklirik suatu lagu pada suatu acara misalnya pernikahan, bisa saja digunakan untuk acara turun mandi, yang penting maknanya sampai dan cocok.

Nilai-nilai yang terkandung dalam tradisi lisan biduk sayak yaitu nilai budaya, moral, dan religius. Nilai budaya yang ditemukan yaitu ketakwaan, bersyukur, kerukunan, kasih sayang, harapan, pengorbanan, keikhlasan, kesopanan, dan memberi nasihat, Selanjutnya nilai moral yang ditemukan dalam tradisi lisan biduk sayak yaitu tolong menolong dan saling menghargai. Nilai religius yang ditemukan ialah akhlak, keikhlasan, dan kedisiplinan.

\section{Daftar Pustaka}


.1998. Seri Tradisi Lisan Nusantara. Dalam Metodologi Kajian Tradisi Lisan. Editor Pudentia MPSS. Yayasan Obor Indonesia. Jakarta.

A. Safutri, Ria. 2014. Revitalisasi Ataraksi Wisata Sebagai Daya Tarik Dusun Kentingan di Desa Tirtoadi, Kecamatan Mlati, Kabupaten Sleman, Daerah Istimewa Yogyakarta. Skripsi. Fakultas Ilmu Budaya, Universitas Gadjah Mada. Yogyakarta.

Abdulsyani. 1994. Sosiologi, Skematika, Teori, dan Terapan. Jakarta: Bumi Aksara.

\section{Sosiologi: Skematika,} Teori dan Penerapannya. Jakarta: Bumi Aksara.

Audah, Ali. 2016. Teori Diferensiasi Luhmann dalam Masyarakat Modern: Sebuah Refleksi Fenomenologis pada Kasus Pengkhususan Lahan Parkir di Kawasan RSGM UGM. http://www.reseachgate.net/publ ication/309630640 diakses 19 januari 2018 (08:45).

Danandjaja, James. 1986. Foklor Indonesia: ilmu gosip, dongen dan lain-lain. Jakarta: PT Pustaka Grafitipers.

Depdiknas. 2008. Kamus Besar Bahasa Indonesia Pusat Bahasa. Jakarta: PT Gramedia

Duija, I Nengah. 2005. Tradisi Lisan, Naskah dan Sejarah: Sebuah Catatan Kebudayaan. Depok: Jurnal Wacana. Vol 7, No. 2: 111-124.

Edraswara, Suwardi. 2015. Penulisan Laporan Penelitian Tradisi
Lisan. Pelatihan Pelestari Tradisi Lisan Tingkat Dasar.

Hatmiati. 2016. Revitalisasi Pemali Dalam Tradisi Lisan Orang Banjar.Seminar Nasional "Budaya Lokal dalam Sastra" dalam rangka Pelantikan Pengurus Himpunan Sarjana Kesusastraan Indonesia (HISKI) Komisariat Universitas Lambung Mangkurat (ULM) Periode 2016-2020. 2 Juni (11:58).

Ikbar, Yanuar. 2014. Metode Penelitian Sosial Kualitatif. Bandung: PT Refika Aditama.

Irni, Ismunandar dan Henny Sanulita.

$\begin{array}{lr} & \text { Revitalisasi Tari } \\ \text { Redad di } & \text { Kelurahan Tanjung } \\ \text { Kecamatan } & \text { Mempawah Hilir } \\ \text { Kabupaten } & \text { Pontianak. } \\ \text { Pontianak: } & \text { Universitas } \\ \text { Tanjungpura. } & \end{array}$

Kartasasmita, Ginanjar. 1997. Karakteristik dan Struktur Masyarakat Indonesia Modern. Sarasehan uji sahih atas pokokpokok pikiran Golkar tentang GBHN 1998. 29 Juni.

Liberty, Eva.M.B. 2014. Tradisi Sanggring di Desa Gumeno Kecamatan Manyar Kabupaten Gresik Jawa Timur: Studi atas Makna dan fungsi. Skripsi, Fakultas Adab dan Ilmu Humaniora, Universitas Islam Negeri Sunan Kalijaga.

Maulid. 2012. Tradisi lisan Kagaa Dalam Masyarakat Muna di Sulawesi Tenggara, Perubahan dan Keberlanjutannya. Tesis, Fakultas Ilmu Pengetahuan Budaya, Universitas Indonesia.

Mondodalo, Darminton. 2016. Tradisi Kasambu Masyarakat Muna 
Sulawesi Tenggara: Kajian Struktur, Konteks, Penuturan, Proses Penciptaan, dan Fungsi Serta Pemanfaatan Hasilnya Untuk Menyusun Bahan dan Kegiatan Pembelajaran Sastra di SMA. Repositry.upi.edu. diakses 12 februari 2018 (21.48)

Pudentia. 2012. Pengelolaan Tradisi Lisan Sebagai Warisan Budaya. http://www.academia.edu/98455 72/Pengelolaan_Tradisi_Lisan Sebagai_Warisan_Budaya. Diakses pada 26 Desember 2017 (06:50) . 2015. Peran Tradisi Lisan dalam Membangun Peradaban Masyarakat Ekonomi Asean. Konferensi Internasional IKABUDI IV. Jember, 8-9 Oktober 2014

Rohim, Khairir dan Rustam. E. 2012. Nilai Budaya Dalam Mantra Banjar. Banjarmasin: Jurnal Bahasa dan Sastra. Vol 2, No 2: 204-214.

Rosana, Ellya. 2011. Modernisasi dan Perubahan Sosial. Lampung: Jurnal TAPis. Vol 7, No 12: 3147.

Sari, Darwan. 2011. Revitalisasi tradisi lisan kantola Masyarakat muna Sulawesi Tenggara Pada era globalisasi. Tesis Pascasarjana, Universitas Udayana.

Soehadi. - Nilai-Nilai Tradisi Lisan Dalam Budaya Jawa. http://journal.ugm.ac.id/jurnalhumaniora/article/view/763.

Diakses 12 januari 2018 (07:43).

Solekah. 2015. Nilai-Nilai Budaya Dalam Cerita Rakyat Dari Jambi Edisi 2. Skripsi, Fakultas Keguruan dan Ilmu Pendidikan, Universitas Jambi. Jambi
Sunarti. 2008. Nilai-Nilai Budaya Dalam Novel Tiba-Tiba Malam Karya Putu Wijaya: Tinjauan Semiotik. Skripsi, Fakultas Keguruan dan Ilmu Pendidikan, Universitas Muhammadiyah Surakarta.

Takari, Muhammad. 2013. Tradisi Lisan di Alam Melayu Arah dan Pewarisannya. Medan: Universitas Sumatera Utara. 